Far Eastern Entomologist

\begin{tabular}{lll}
\hline Number 419: 18-28 & ISSN 1026-051X (print edition) & November 2020 \\
\hline
\end{tabular}

https://doi.org/10.25221/fee.419.3

http://zoobank.org/References/9E41E6B7-7200-42A2-881F-30FAEE8484E4

\title{
A NEW SPECIES OF THE PRAYING MANTIS GENUS EUCHOMENELLA GIGLIO-TOS, 1916 (MANTODEA: DEROPLATYIDAE) FROM THAILAND
}

\section{T. Unnahachote ${ }^{1)}$, Y. Samung ${ }^{2 *}$, W. Jaitrong ${ }^{3)}$}

1) Department of Entomology, Faculty of Agriculture, Kasetsart University, Nakhon Pathom,73140Thailand.E-mail:flukun@gmail.com

2) Department of Medical Entomology, Faculty of Tropical Medicine, Mahidol University, 420/6 Ratchawithi Road, Ratchathewi, Bangkok, 10400, Thailand. *Corresponding author, E-mail: yudthana.sam@mahidol.ac.th

3) Natural History Museum, National Science Museum, Technopolis, Khlong 5, Khlong Luang, Pathum Thani, 12120, Thailand.E-mail:polyrhachis@yahoo.com

Summary. A new species, Euchomenella kasetsart sp. n., is described based on the male and female collected from Nakhon Pathom Province, central Thailand. The new species can be easily distinguished from other Oriental congeners by the smaller pronotal proportion.

Key words: mantises, Deroplatyinae, Euchomenellini, taxonomy, new species, Oriental Region.

Т. Уннахачоте, Ю. Самунг, В. Ятронг. Новый вид богомолов рода Euchomenella Giglio-Tos, 1916 (Mantodea: Deroplatyidae) из Таиланда // Дальневосточный энтомолог. 2020. N 419. С. 18-28.

Резюме. Из провинции Накхонпатхом в центральном Таиланде по самцам и самкам описан новый для науки вид Euchomenella kasetsart sp. n. Этот вид отличается от всех ориентальных видов рода меньшими пропорциями переднеспинки.

\section{INTRODUCTION}

The genus Euchomenella was established by Giglio-Tos (1916) as belonging to the family Mantidae (Angelinae), with Mantis heteroptera de Haan, 1842 as the type species, and comprises stick-like praying mantises with the length of metazona at least 3.6 times as long as the prozona (Vermeersch, 2018a). Recently, this genus was transferred to the family Deroplatyidae (Deroplatyinae: Euchomenellini) (Ehrmann, 2002; Schwarz \& Roy, 2019) based on the result of molecular phylogenetic reconstructions, external morphology and genitalia structure. Currently, eight species are known from Southeast Asia, namely Euchomenella adwinae Vermeersch, 2018 from S Vietnam, E. apicalis Werner, 1922 from Indonesia (NE Sumatra, Java), E. heteroptera (De Haan, 1842) from Malaysia (Malay Peninsula, Borneo: Sarawak, Sabah), Indonesia (Sumatra, S Java, N Sulawesi, and Kalimantan), Philippines (Luzon) and Singapore, E. macrops (Saussure, 1870) from S Vietnam and Thailand, E. matilei Roy, 2001 from Malaysia (Borneo: Sabah) and Brunei, E. molucarum (Saussure, 1872) from Indonesia (Moluccas Island) and Malaysia, E. thoracica (De Haan, 1842) 
from Indonesia (Sulawesi and Sunda Island), and E. udovichenkoi Scherbakov, 2012 from Malaysia (Borneo: Sabah) (Otte et al., 2020). Of them, the only E. macrops has been recorded from Thailand (Roy, 2001; Shcherbakov, 2012).

Surveys of praying mantises in Kasetsart University Kamphaeng Saen Campus, Nakhon Pathom Province, central Thailand led to the discovery of a few unidentified Euchomenella specimens. Having carefully compared with the type material and material from the type locality of closely related species, we concluded that this species is new to science. The description of this species is given below.

\section{MATERIAL AND METHODS}

The material was collected from Nakhon Pathom Province in 2018-2019. The holotype and paratypes of the new species are pin-mounted dry specimens. Male genitalia were removed from the tip of the abdomen then soaked in $10 \%$ potassium hydroxide solution for one day, and put in glycerin for detailed observation. The type material was compared with high resolution images of E. macrops (see: Muséum National D'Historire Naturelle, https:// science.mnhn.fr/institution/mnhn/collection/ep/item/ep2517?listIndex $=6 \&$ listCount $=6 \& \mathrm{fbcli}$ d=IwAR0J6AkqBhZupSOy7sMa75FIr9AnBOtSv_pQLFYZsWDci03EWZIFy1Q1qo.) and E. adwinae (provided by Dr. Xavier Vermeersch). Observation of the external structures, male genitalia and coloration was done with an OPTIKA ${ }^{\circledR}$ microscope (OPTIKA Microscopes Italy). Photographs of external morphology were taken with a Nikon AF-S Micro NIKKOR 60mm lens attached to a Nikon D7200. Multi-focused montage images of the male genitalia were produced using NIS-Elements-D from a series of source images taken with a Nikon Digital Sight-Ril camera attached to a Nikon AZ100M stereoscope. Distribution map was made with SimpleMappr (Shorthouse, 2010).

Terminology of the external morphology and male genitalia follow Brannoch et al. (2017) and Schwarz \& Roy (2019). Prothoracic leg spine arrangement from the proximal to the distal end represented by "I" follows Vermeersch (2018a). All measurements were done with a digital caliper (accurate to $0.01 \mathrm{~mm}$ ) following the measurement standards by Vermeersch (2018b).

The follow abbreviations are used in text and figures: afa - phalloid apophysis; AvS anteroventral spine; bl - basal lobe of ventral phallomere; DS - discoidal spine; fda - main posterior lobe of right phallomere; MzL - metazona length; paa - apical process of left phallomere; pia - process posterolateral to pva of right phallomere; PL - pronotum length; pva - process anteromesal to pia of right phallomere; PvS - posteroventral spine; PzL prozona length.

COMPARATIVE MATERIAL EXAMINED. Euchomenella macrops (Saussure, 1870) (Figs 3A, 4B, 5A, 5B): Thailand: Chanthaburi Prov., Kitchakut Dist., Krathing Resort, $12^{\circ} 49^{\prime} \mathrm{N}, 102^{\circ} 07^{\prime} \mathrm{E}, 29$.VI $2019,1{ }^{\top}, \mathrm{T}$. Unnahachote leg. (author's collection). Vietnam: Cat Tien National Park (N.P.), $11^{\circ} 26^{\prime} \mathrm{N}, 107^{\circ} 26^{\prime} \mathrm{E}, 6-16$.VII 2012, 1 , J. J. Constant and J. Bresseel, I.G.: 32.161 (RBINS, photo by Xavier Vermeersch); Dong Nai (N.P.), $11^{\circ} 26^{\prime} \mathrm{N}$, $107^{\circ} 26^{\prime} \mathrm{E}, 6-16$. VII 2012, $1 \mathrm{O}^{\mathrm{N}}$, J. Constant and J. Bresseel, I.G.: 32.161 (RBINS, photo by X. Vermeersch); Dong Nai Biosphere Res., $11^{\circ} 18^{\prime} \mathrm{N}, 107^{\circ} 06^{\prime}$ E, 25.VI.-6.VII 2012, 3ㅇ, J. Constant and J. Bresseel, I.G.: 32.161 (RBINS, photo by X. Vermeersch); Cat Tien (N.P.), $11^{\circ} 26^{\prime} \mathrm{N}, 107^{\circ} 26^{\prime} \mathrm{E}, 6-16 . \mathrm{VII}$ 2012; 1웅. J. Constant and J. Bresseel leg., I.G.: 32.161 (RBINS, photo by X. Vermeersch); Tonkin, Reg. De Hoa-Binh, A. De Cooman, 1928, 1 ㅇ (MHNH-EP-EP2517, Photo copyright MNHN). Euchomenella adwinae Vermeersch, 2018 (Fig. 3C): Vietnam:, Ninh Thuan Prov., Núi Chúa N.P., $11^{\circ} 42^{\prime} \mathrm{N}, 109^{\circ} 09^{\prime} \mathrm{E}$, night collecting, 3-9.X 2014, 1 \& (holotype), J. Constant and J. Bresseel leg., GTI project, I.G.: 32.779 (RBINS, photo by X. Vermeersch).

Abbreviations of the type depositories and others are as follows: MHNH - National Museum of Natural History, Paris, France; RBINS - Royal Belgian Institute for Natural Sciences, Brussels, Belgium; THNHM - Natural History Museum, Pathum Thani, Thailand. 


\title{
TAXONOMY
}

\author{
Family Deroplatyidae Westwood, 1889 \\ Subfamily Deroplatyinae Westwood, 1889 \\ Tribe Euchomenellini Giglio-Tos, 1916 \\ Genus Euchomenella Giglio-Tos, 1916
}

DIAGNOSIS. Compound eye round. Vertex without spines or tubercles. Pronotum entirely smooth and equal in size to, or longer than, rest of body; metazona distinctly longer than prozona (3.6-5.4 times). Forefemur with four Discoidal spines, of which second is longer than the rest, 14-15 anteroventral spines and four posteroventral spines; inner side of forefemur with two transversely crossed bands which separated femoral area into three equal parts and darkened area near distal end of forecoxa. Internal apical lobes of forecoxa adjacent to each other. Foretibia with 7-8 posteroventral spines. Cerci simple and cylindrical with setae. Female significantly larger than male, with strongly shortened forewings and hindwings measuring less than half of abdominal length. Male with both wings well developed, reaching to tip of abdomen, brownish enfumated.

Euchomenella kasetsart Unnahachote, Samung et Jaitrong, sp. n. http://zoobank.org/NomenclaturalActs/8DFECD3F-B93E-4CF1-A5D8-8AF779BEF643

Figs 1, 2, 3B, 4A, 5C, 5D, 6

TYPE MATERIAL. Holotype - $\hat{\jmath}$ (THNHM-I-14183, THNHM), Thailand: Nakhon Pathom Province, Kasetsart University Kamphaeng Saen Campus, $14^{\circ} 02^{\prime} \mathrm{N}, 99^{\circ} 58^{\prime} \mathrm{E}, 28 . \mathrm{V}$ 2018, T. Unnahachote leg. Paratypes: Thailand: same data as for holoytype, 1 (THNHMI-14184, THNHM); same locality, 2.XI 2019, 1 त, T. Klombanchong leg. (RBINS, IG:34.123); same locality, 29.X 2019, 1 ㅇ, T. Unnahachote leg. (RBINS, IG:34.123).

DESCRIPTION. Male. Head. Wider than long; compound eye large and round, slightly projecting anteriorly, suboval in lateral view; vertex slightly concave; ocelli well developed forming a triangular shape; ocellar tubercle distinct; antennae longer than in female, filiform, first segment as long as other two segments combined; lower frons transverse, apical margin distinctly convex, and round.

Pronotum. Metazona slender, approximately 3.7 times as long as prozona and slightly shorter than forewing; anterior end of prozona with a pair of small depressions; lateral margin with very small spines, distinct on prozona but indistinct on metazona; supracoxal dilation small but distinct, rounded, dark brown-black at lateral margin under supracoxal sulcus; supracoxal sulcus distinct; medial keel running from supracoxal sulcus to posterior margin of pronotum, with two elevations close to each other at the end of medial keel; in ventral view, a pair of small, yellowish marks on posterior half.

Prothoracic legs. Coxa slender, darkened apically, shorter than metazona and femur, anteroventral margin with six to eight small spines and one to three tubercle developed between spines; coxal lobe divided, anterior surface clearly smooth; trochanter with distinct black marking in ventral view; femur slender, distal half of anterior margin slightly concave, anterior margin with a row of tubercles from base to first DS; four DSs, with fourth shortest and third longest, third and second black at base in ventral view, third DS almost black and others black apically; $15 \mathrm{AvS}$ unequal in size and arranged in pattern IIIIIIIIIIIIII (in left femur of paratype (RBINS), $14 \mathrm{AvS}$ arranged in pattern IIIIIIIIIIIIII); in ventral view, AvS $1-8,10$ and 15 entirely dark (AvS 14 entirely black in holotype but lost on left forefemur of 
paratype (RBINS), although not deep black on right forefemur); two distinct black patches, one at middle between first DS and base, the other consisting of eight AvS and anterior half of claw groove; femoral brush area almost black with four $\mathrm{PvS}$ all black apically except for second, which is entirely darken; in dorsal view, tibia with 12-13 AvS (11-12 AvS in paratype RBINS), and seven PvS (7-8 PvS in paratype RBINS), with all spines black only at apex; three somewhat distinct black patches in ventral view at proximal part, middle and base of tibial spine; metatarsus black in proximal half and at tip, with rests black apically.
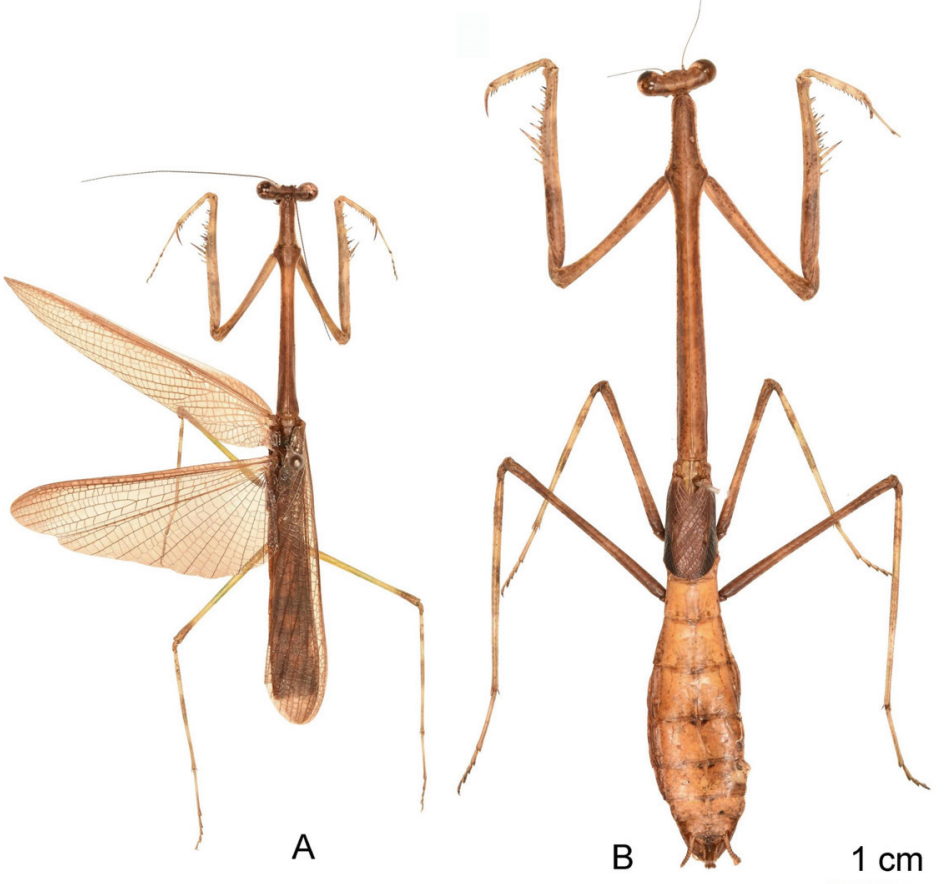

Fig. 1. Euchomenella kasetsart sp. n., dorsal view. A - holotype male; B - paratype female.

Mesothoracic and metathoracic legs. Slender; middle leg shorter than hind leg, with two or three somewhat distinct bands (right middle leg lost in holotype); femora with hairs, hairs denser on tibiae and metatarsus; tibiae with two tibial spurs; metatarsus longer than other tarsal segments combined.

Forewing and hindwing. Forewing uniformly brown and smoky; costal area semitransparent in basal third, rest hyaline; subcostal area and stigma semi-opaque, with low cell density at anterior margin; hindwing with same coloration and pattern as forewing, but very smoky apically; costal and subcostal area changing from semitransparent to semi opaque from proximal half to distal half; veins brownish, with darker coloration along cross veins, with low cell density at anterior margin.

Abdomen. Eight visible coxosternites; supra-anal plate (tergite 10) transverse, posterior margin round with occasional setae. Cerci simple, cylindrical with 11 segments, 11 th conical (Fig. 2E); posterior margin of subgenital plate (coxosternite 9) concave with short, robust styli, setae regularly spaced on ventral surface but slightly longer and denser at posterior margin (Fig. 2D). 


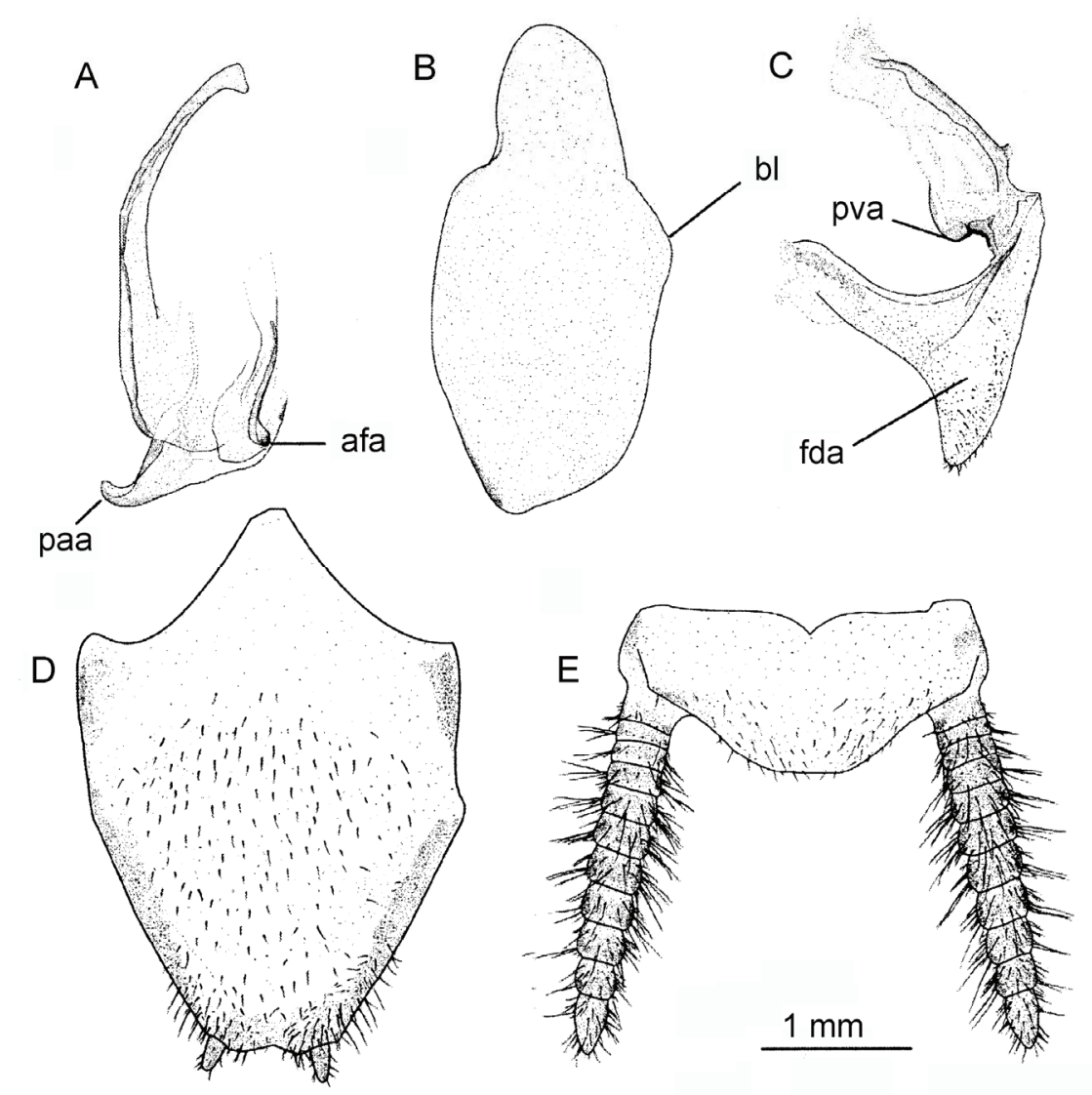

Fig. 2. Euchomenella kasetsart sp. n., male genitalia and terminalia, dorsal view. A - left phallomere; B - ventral phallomere; C - right phallomere; D - subgenital plate; E - supraanal plate.

Male genitalia. (Fig. 2A-C). Right phallomere: fda elongated with few setae at apex; pva well sclerotized, short. Ventral phallomere: elongated, twice as long as broad, anterior end distinctly narrow with a round apex, left margin of posterior end slightly sclerotized; bl rounded. Left phallomere: paa narrowing towards apex, somewhat sclerotized with distal end shaped like a hook; afa not elongated, round without a medial concavity on right surface, well sclerotized and entirely covered by dense small spines that are only visible under high magnification.

MEASUREMENTS (in mm, values for the paratype in parentheses). Total length 45.4 (45.2); head width 5.1 (4.9); head height 2.5 (2.3); foretibia length 4.7 (4.8); forefemur length 11.2 (11.4); forecoxa length 9.0 (8.9); pronotum length 18.1 (18.1); pronotum width 2.2 (2.2); prozone length 3.8 (3.8); metazone length 14.3 (14.3); middle femur length 9.2 (9.4); middle tibia length 7.7, broken in holotype (8.5); hind femur length 12.0 (12.3); hind tibia length 11.4 (11.4); forewing length 25.7 (24.8); hindwing length 22.4 (22.0). 
Female. Head. Wider than long, compound eye large and round, slightly projecting anteriorly, suboval in lateral view; vertex slightly concave. Ocelli smaller than in male; ocellar tubercle difficult to recognize; antennae shorter than those of male.

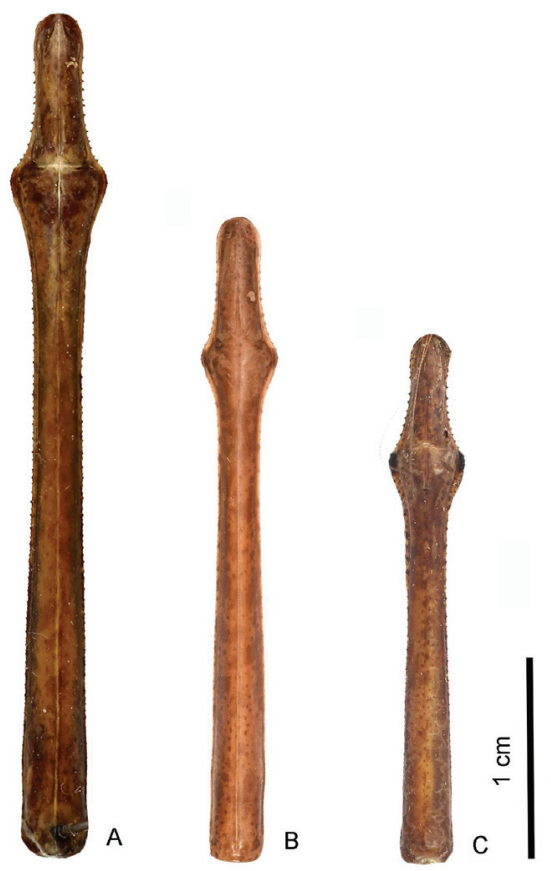

Fig. 3. Female pronotum of Euchomenella spp. A - E. macrops; B - E. kasetsart sp. n.; $\mathrm{C}-$ E. adwinae.
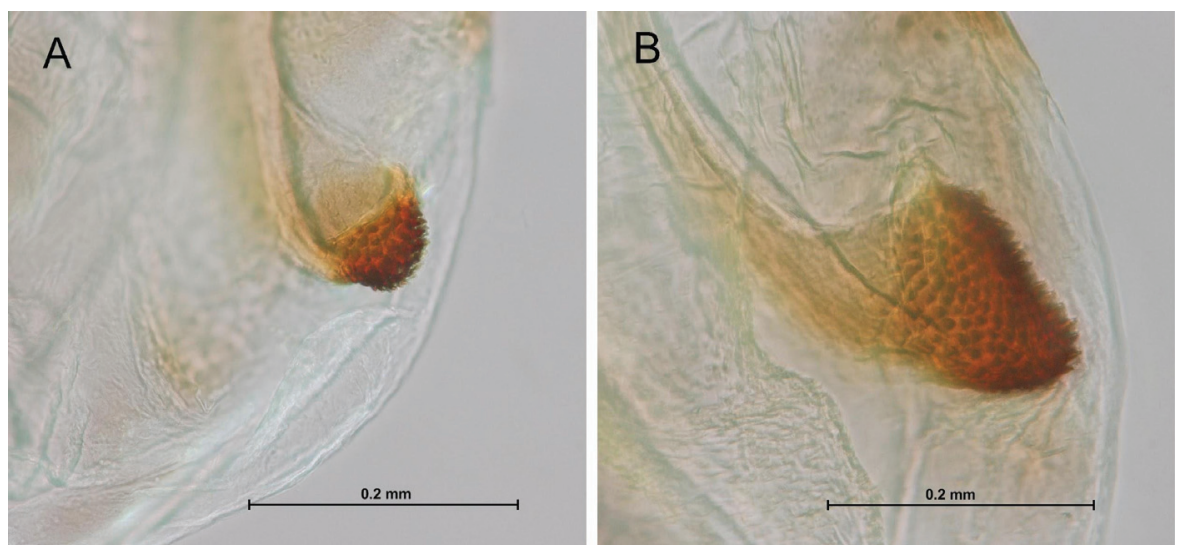

Fig. 4. Phalloid apophysis of Euchomenella spp. A - E. kasetsart sp. n., B - E. macrops. 
Pronotum. Metazona slender, approximately 4.15-4.26 times as long as prozona; anterior end of prozona bearing a pair of small depressions; supracoxal dilation dark brownblack at lateral margin under supracoxal sulcus; more distinct small spines present along pronotal margin, very distinct at prozona; medial keel from supracoxal sulcus to posterior margin of pronotum with two elevations close to each other at end of the keel; a pair of small yellowish marks on the posterior half in ventral view.

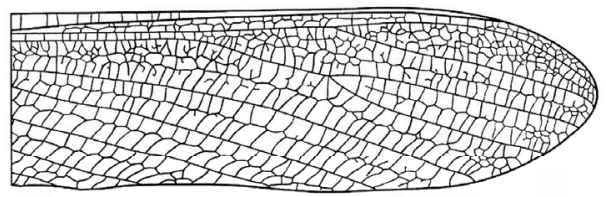

\section{A}

$5 \mathrm{~mm}$
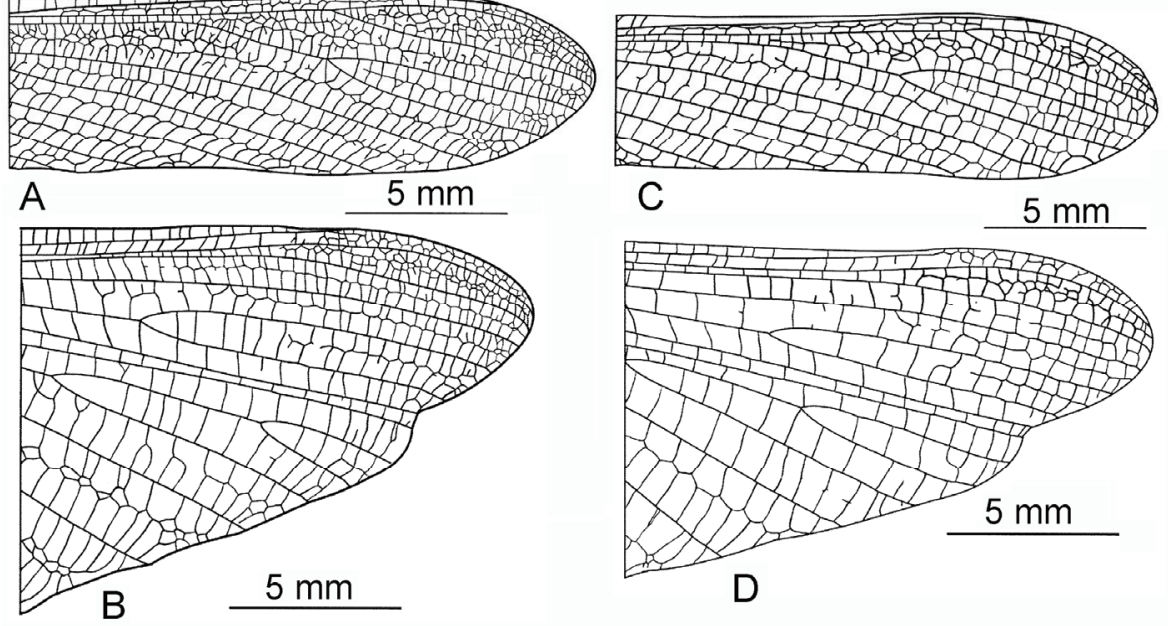

C

$5 \mathrm{~mm}$

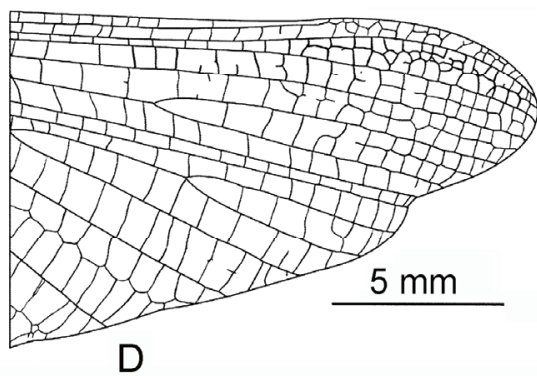

Fig 5. Male right forewings (A, C) and hindwings (C, D) of Euchomenella spp. A, B - E. macrops; C, D - E. kasetsart sp. n., paratype.

Prothoracic legs. Coxa slender, darkening apically, shorter than metazona and femur, anteroventral margin with seven to nine small spines of same color as the coxa but white in live specimen, with two to five tubercles developed between spines; coxal lobe divided, with a clearly smooth anterior surface; trochanter with black marking in ventral view (marking indistinct in dried specimens); femur slender, anterior margin in distal half slightly concave with row of tubercles from base to first DS; four DSs, with fourth shortest and third longest, second and third black at base of the spine in ventral view, third DS almost black at the anterior surface, others black apically; $15 \mathrm{AvS}$ arranged in pattern IIIIIIIIIIIIIII (in left forefemur of paratype RBINS), 14 AvS arranged in pattern IIIIIIIIIIIIII); in ventral view, AvS 2, 4, 6, 8, 10 and 15 entirely black, with AvS 14 on left forefemur also black; AvS 1, 3, 5 and 7 almost black (entirely black in paratype THNHM); two distinct black patches present, one in middle between first DS and base, the other consisting of eight AvS and anterior half of claw groove; femoral brush area almost black with four PvS all black apically, second and third equal in length; tibia with 12-13 AvS, with three somewhat distinct black patches at proximal part, middle, and base of tibial spine in ventral view; seven $\mathrm{PvS}$; all spines black only at tip; metatarsus black in proximal half and at tip, others black apically (almost lost in paratype THNHM).

Mesothoracic and metathoracic legs. Middle leg shorter than hind leg with two or three somewhat distinct bands; femora with hairs; hairs much denser on tibiae and metatarsus; metatarsus longer than other tarsal segments combined. 
Forewing and hindwing. Forewing uniformly brown, short, and opaque, reaching posterior margin of first visible tergite; hindwing completely covered by forewing.

Abdomen. Six visible coxosternites; supra-anal plate (tergite 10) transverse, posterior margin slightly concave with occasional setae; cerci simple, cylindrical with 13 segments, 13th conical.

MEASUREMENTS (in mm, values for the second paratype in parentheses). Total length 69.2 (67.3); head width 7 (6.8); head height 4.4 (4.2); foretibia length 6.6 (6.9); forefemur length 18.1 (18.1); forecoxa length 14.9 (14.9); pronotum length 31.4 (32.1); pronotum width 3.6 (3.6); prozone length 6.1 (6.3); metazone length 25.3 (26.8); middle femur length 14.3 (15.0); middle tibia length 13.4 (13.7); hind femur length 18.1 (18.7); hind tibia length 19.6 (19.8); forewing length $8.9(9.0)$.

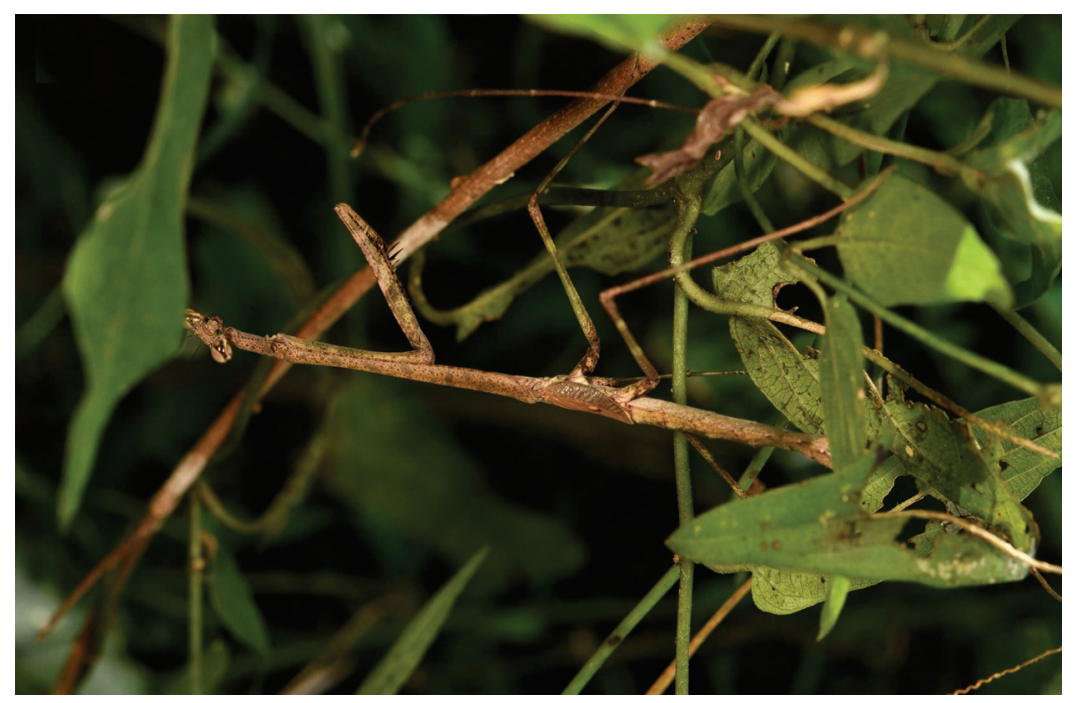

Fig. 6. Live specimens of Euchomenella kasetsart sp. n., paratype female (RBINS, IG:34.123)

DIFFERENTIAL DIAGNOSIS. Both sexes of the new species have distinctly smaller body lengths and ratios of MzL/PzL than the other known Euchomenella species: MzL/PzL 4.15-4.26 in the female and 3.76 in the male for Euchomenella kasetsart sp. n., compared with at least 4.9-5.4 for all other Oriental species. In addition, the new species can be distinguished from the two Vietnamese species as follows.

Euchomenella kasetsart sp. n. can be distinguished from E. adwinae (male unknown) by the following characteristics: 1) the second PvS of the forefemur is black apically and equal in length to the third PvS (entirely black and longer than the third PvS in E. adwinae);2) the ninth AvS of the foretibia is black apically (entirely black in E. adwinae); and 3 ) the ratio of $\mathrm{MzL} / \mathrm{PzL}$ is 4.15-4.25 (Fig. 3B) (3.6 in E. adwinae; see Vermeersch, 2018).

Euchomenella kasetsart sp. n. can be distinguished from E. macrops by the following characteristics: 1) the wings are uniformly brown, forewing having sparser cells at the anterior margin and on apical lobe (Fig. 5C), hindwing sparser cells on apical lobe (Fig. 5D) and a darker field along the cross veins especially on the anal area (in E. macrops wings are 
not uniformly brown, with denser cells at the anterior margin of the apical lobe of the forewing and hindwing (Figs 5A, 5B), and the cross veins on the anal area with a distinctly bright field along the veins in the male); 2) the cerci have 11 distinct segments in the male (Fig. 2E) (in E. macrops cerci with 14 distinct segments); 3) both sides of the anterior half of the ventral phallomere are strongly concave and somewhat round (Fig. 2B) (in E. macrops they are slightly concave and somewhat sloping); 4) afa is clearly shorter, without a medial concavity on the right surface (Fig. 4A) (in E. macrops it is more elongated with a medial concavity on the right surface, Fig. 4B); 5) the subgenital plate have robust styli and a clearly concave posterior margin (Fig. 2D) (in E. macrops the styli are less robust and the posterior margin is usually truncated).

DISTRIBUTION. This species has been known only from the type locality (Fig. 7).

ETYMOLOGY. The specific name is after the type locality, Kasetsart University, Kasetsart University Kamphaeng Saen Campus, central Thailand.

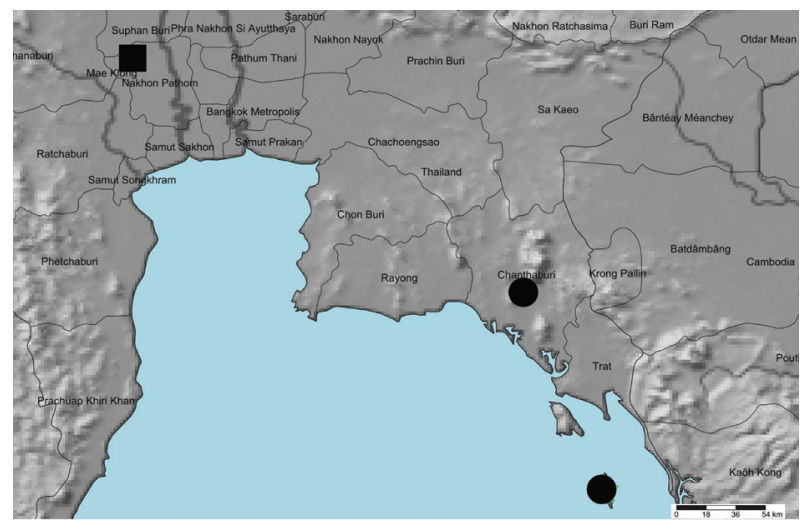

Fig. 7. Distribution of Euchomenella spp. in Thailand. - - E. kasetsart sp. n.; • - E. macrops.

\section{DISCUSSION}

This report describes the second species of Euchomenella to be recorded in Thailand. The first species E. macrops (Saussure, 1870) has been found in Trat and Chanthaburi Provinces (Shcherbakov, 2012; present study) in eastern Thailand (Fig. 7). The new species was collected from a very small degraded forest in Kamphaeng Saen Campus of Kasetsart University. The campus is in Nakhon Pathom Province in the western part of the Lower Central Plain. It is surrounded by mountain ranges, including the Phetchabun mountain range to the west and the western end of Khorat plateau to the east. Nevertheless, the Lower Central Plain includes a densely populated urban area and there has been human activity in the region throughout prehistoric and historic periods. In addition, it is regarded as an important agricultural area of Thailand (Bunopas \& Vella, 1983; Sinsakul, 2000; Vanasin \& Supajanya, 1981). These factors could act as a biogeographic barrier isolating the new species from species inhabiting areas with undisturbed, species-rich forests. One species of mantid recently found to be surviving in a small, degraded area of forest is Chlorocalis maternashulzei Stiewe, Vermeersch \& Shcherbakov, 2019 which was collected from Yeak Laom secondary forest in Cambodia (Vermeersch et al., 2019). However, the collecting area of E. kasetsart sp. n. differs from the latter in that it is an extremely small degraded area of forest located on a university campus surrounded by roads, rice fields and many buildings (Fig. 8). This raises 
the question about how the species has managed to survive and how long it can continue to survive if its habitat is not maintained through conservation in the future. The finding of this new species suggests that further taxonomic research on the entomofauna of Thailand could result in the discovery of more new species or at least provide record of Mantodea in Thailand, both in less disturbed forests and in forest areas that have been highly degraded.

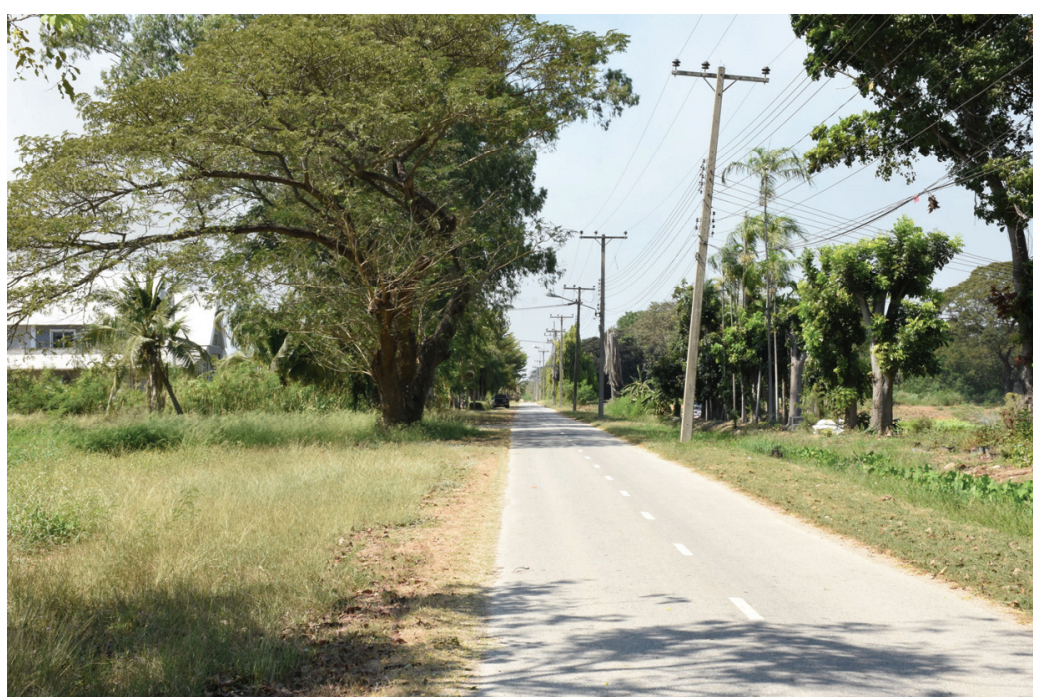

Fig. 8. Habitat of Euchomenella kasetsart sp. n., showing a small degraded forest in the Kasetsart University Kamphaeng Saen Campus, in which the specimens were collected.

\section{ACKNOWLEDGEMENTS}

We would like to express our deep gratitude to Xavier Vermeersch (Royal Belgian Institute of Natural Sciences) and Evgeny Shcherbakov (Lomonosov Moscow State University, Russia) who provided their expertise, gave evaluable comparative material pictures and read the earlier draft of the manuscript. We would also like to express our deep gratitude to Professor Seiki Yamane (Kagoshima University) for critical reading of an earlier draft of the manuscript. We thank Faculty of Tropical Medicine, Mahidol University for English editing support. Lastly, we thank also Mr Jeerasak Korkoonklang, Mr Thanachit Klombanchong and Mrs Kanyanat Koonkum for their helping in a field survey.

\section{REFERENCES}

Brannoch, S.K., Wieland, F., Rivera, J., Klass, K.D., Béthoux, O. \& Svenson, G.J. 2017. Manual of praying mantis morphology, nomenclature, and practices (Insecta, Mantodea). ZooKeys, 696: 1-100. DOI: https:/doi.org/10.3897/zookeys.696.12542

Bunopas, S. \& Vella, P. 1983. Opening of the Gulf of Thailand, Rifting of continental Southeast Asia and Late Cenozoic Tectonics. Journal of the Geological Society of Thailand, 6(1): 1-12.

Ehrmann, R. 2002. Mantodea: Gottesanbeterinnen der Welt. Natur und TierVerlag GmbH (NTV), Munster, Germany. 519 pp.

Giglio-Tos, E. 1916. Mantidi esotici. Generi e specie nuove. Bullettino della Società Entomologica Italiana, 47:3-44. 
Otte, D. Spearman, L. Stiewe M.D.D. 2020. Mantodea Species File Online. Version 5.0/5.0. Visited 5 July 2020. Available from: http:/Mantodea.SpeciesFile.org

Roy, R. 2001. Contribution à la connaissance des Angelinae de la région orientale: les genres Euchomenella, Mythomantis et Tagalomantis (Dictyoptera, Mantidae). Revue française d'Entomologie (N. S.), 23 (1):79-92.

Schwarz, C.J., Roy, R. 2019. The systematics of Mantodea revisited: an updated classification incorporating multiple data sources (Insecta: Dictyoptera). Annales de la Société entomologique de France (N.S.), 55 (2): 101-196. DOI: https://doi.org/10.1080/ 00379271.2018 .1556567

Shcherbakov, E.O. 2012. New data on the genera Euchomenella and Tagalomantis (Dictyoptera: Mantidae: Angelinae). Zoosystematica Rossica, 21(2): 270-278.

Shorthouse, D.P. 2010. SimpleMappr: an online tool to produce publication-quality point maps. Visited 5 July 2020. Available from: https://www.simplemappr.net/

Sinsakul, S. 2000. Late Quaternary geology of the Lower Central Plain, Thailand. Journal of Asian Earth Sciences, 18(4): 415-426. DOI: https://doi.org/10.1016/S1367-9120 (99)00075-9

Vanasin, P. \& Supajanya, T. 1981. Ancient Cities on the Former Coastline of Central Thailand. Chulalongkorn University, Bangkok.

Vermeersch, X.H.C. 2018a. Euchomenella adwinae sp. nov., a small stick mantis from southern Central Vietnam (Mantodea: Mantidae: Deroplatyinae: Euchomenellini). Belgian Journal of Entomology, 63: 1-9.

Vermeersch, X.H.C. 2018b. Phasmomentella gen. nov., a spectacular new genus of praying mantis from southern Central Vietnam (Mantodea, Mantidae, Deroplatyinae, Euchomenellini). European Journal of Taxonomy, 442: 1-17. DOI: https://doi.org/10.5852/ ejt.2018.442

Vermeersch, X.H.C., Stiewe, M.B.D., Shcherbakov, E.O. 2019. A new genus of praying mantis, Chlorocalis n. gen., with two new species from the Greater Mekong region (Mantodea: Mantidae), Annales de la Société entomologique de France (N.S.), 55(2): 197-210. DOI: https://doi.org/10.1080/00379271.2018.1562380

Werner, F. 1922. Zur Kenntnis der Mantodeenfauna der niederländischen Kolonien. Zoologische Mededeelingen uitgegeven vanwege's Rijks Museum van Natuurlijke Historie te Leiden, 7(1-2): 115-126.

(C) Far Eastern entomologist (Far East. entomol.) Journal published since October 1994. Editor-in-Chief: S.Yu. Storozhenko

Editorial Board: A.S. Lelej, S.A. Belokobylskij, M.G. Ponomarenko, E.A. Beljaev, V.A. Mutin, E.A. Makarchenko, A.V. Gorochov, T.M. Tiunova, M.Yu. Proshchalykin, S.A. Shabalin

Address: Federal Scientific Center of the East Asia Terrestrial Biodiversity (former Institute of Biology and Soil Science), Far East Branch of the Russian Academy of Sciences, 690022, Vladivostok-22, Russia.

E-mail: storozhenko@biosoil.ru web-site: http://www.biosoil.ru/fee 